\title{
Protecting the Coastline from the Effects of Climate Change: Adaptive Design for the Coastal Areas of Gangneung, Korea
}

\author{
Yumi Lee \\ Department of Landscape Architecture, Graduate School of Environmental Studies, Seoul National University, \\ Seoul, South Korea \\ Email: yumil@snu.ac.kr
}

Received 12 May 2015; accepted 27 June 2015; published 30 June 2015

Copyright (C) 2015 by author and Scientific Research Publishing Inc.

This work is licensed under the Creative Commons Attribution International License (CC BY). http://creativecommons.org/licenses/by/4.0/

(c) (i) Open Access

\section{Abstract}

The purpose of this research is to present design strategies to enable coastal areas to adapt to climate change and maintain the coastlines by addressing the environmental and urban issues. Gangneung is a tourist attraction situated on South Korea's east coast, and there is an urgent need for integrated research on strategies to prevent the loss of sandy beaches and the damage caused by storm surges and high swell. This research has two objectives: The first is to offer an overview and describe the characteristics of exemplary projects carried out to manage the storm damage while maintaining the coastlines. The second is to propose a design model that can be applied to coastal areas susceptible to climate change by analyzing the design strategies and the current conditions of the Gangneung coastal area. In the case of Gangneung, the damage caused by the storm surges and high swells are more severe compared to inundation caused by sea level rise because of the steep slope and deep water. Therefore, adaptive design strategies are mainly focused on accommodation and retreat strategies that consider these characteristics by moving the coastal roads behind the pine forest and raising the coastal buildings to connect the coast to the forest and to prevent coastal erosion. This research has the potential to be used as an exemplary design adaptation for coastal erosion as well as a basis for regulating the land use policy in areas susceptible to flood by establishing guidelines for publicly funded developments, and preparing long-term relocation plans for the existing coastal developments to create a sustainable and resilient future for the coastal areas.

\section{Keywords}

Coastal Cities, Shoreline Management, Climate Change Adaptation, Waterfront Design 


\section{Introduction}

The need for design strategies in coastal areas to adapt to climate change has become a worldwide priority [1] [2]. Damage caused by flooding and rising sea levels has been directly seen in coastal cities and regions, threatening the sustainability of cities, major infrastructure, and coastal wetlands [3] [4]. South Korea has actively implemented the development plans for coastal areas, particularly as the Korean population is accustomed to living near the coasts for the sake of having a mountain in the back and facing the sea [5]. The majority of the country's major infrastructure, including ports, airports, roads, and power plants, are located in coastal areas, and coastal cities with high populations have been created on reclaimed lands and landfills. This trend in coastal development continues today, and large-scale plans in coastal areas are still being implemented despite the threats from climate change and rising sea levels. The rate of the sea level rise in South Korea is higher than the global average, hence, nationwide integrated research on ways to adapt to this change in coastal areas is urgently required [6] [7].

While previous research has focused on the categorization of the methods and planning strategies of adaptation to rising sea levels for the coastal cities [8], the purpose of this research is to present the design strategies to enable the coastal areas to adapt to climate change and maintain the coastlines by addressing the current environmental and urban issues. The research site is Gangneung, a tourist attraction situated on South Korea's east coast, and there is an urgent need for integrated research on strategies to prevent the loss of sandy beaches and damage from storm surges and high swells. This research has two objectives: The first is to offer an overview and describe the characteristics of exemplary projects carried out to manage storm damage while maintaining the shorelines. The second is to propose design models that can be applied to the coastal areas of Gangneung that are susceptible to climate change by analyzing the adaptation strategies and the site conditions.

\section{Review of Previous Research and Projects}

Previous research categorized the adaptation strategies responding to rising sea levels with axonometric diagrams including the representative systems and site advantages as shown in Table 1 [8]. Among them, the attack strategies are not applicable to the east coast owing to the steep slope and deep water. Therefore, hard/soft protection, accommodation and retreat strategies are predominantly used as adaptation strategies for the coastal areas of Gangneung. While Table 1 provides an overview of the applicable adaptation strategies [8], Table 2 shows the characteristics of exemplary coastal projects designed to cope with the storm damage while protecting the coastal areas and maintaining the shorelines.

\begin{tabular}{|c|c|c|c|c|}
\hline Strategies & Features & Methods & Site advantages & Diagrams \\
\hline Hard protection & $\begin{array}{l}\text { Dikes } \\
\text { Levees } \\
\text { Sea walls } \\
\text { Groins }\end{array}$ & $\begin{array}{l}\text { Build physical } \\
\text { barriers to } \\
\text { block water }\end{array}$ & $\begin{array}{l}\text { For hard-to-move } \\
\text { facilities and } \\
\text { infrastructure } \\
\text { on flat grounds }\end{array}$ & \\
\hline Soft protection & $\begin{array}{l}\text { Mangroves } \\
\text { Wetlands } \\
\text { Sand dunes } \\
\text { Tidal flats }\end{array}$ & $\begin{array}{l}\text { Create buffer } \\
\text { with vegetation } \\
\text { or landforms }\end{array}$ & $\begin{array}{l}\text { For maintaining the } \\
\text { shoreline on the } \\
\text { site with existing } \\
\text { coastal forest } \\
\text { or sand dunes }\end{array}$ & \\
\hline Accommodation & $\begin{array}{l}\text { Raising levels } \\
\text { Desalination } \\
\text { Drainage } \\
\text { Alarm system }\end{array}$ & $\begin{array}{l}\text { Upgrade functions } \\
\text { while retaining the } \\
\text { location }\end{array}$ & $\begin{array}{l}\text { For redevelopment } \\
\text { projects or facilities } \\
\text { on the site without } \\
\text { high grounds nearby }\end{array}$ & \\
\hline Retreat & $\begin{array}{c}\text { Relocation } \\
\text { Abandonment }\end{array}$ & $\begin{array}{c}\text { Relocate } \\
\text { facilities to } \\
\text { low-risk uplands }\end{array}$ & $\begin{array}{c}\text { For residential and } \\
\text { public use facilities } \\
\text { on the site with } \\
\text { low-risk uplands } \\
\text { nearby }\end{array}$ & \\
\hline
\end{tabular}


Table 2. Exemplary coastal projects.

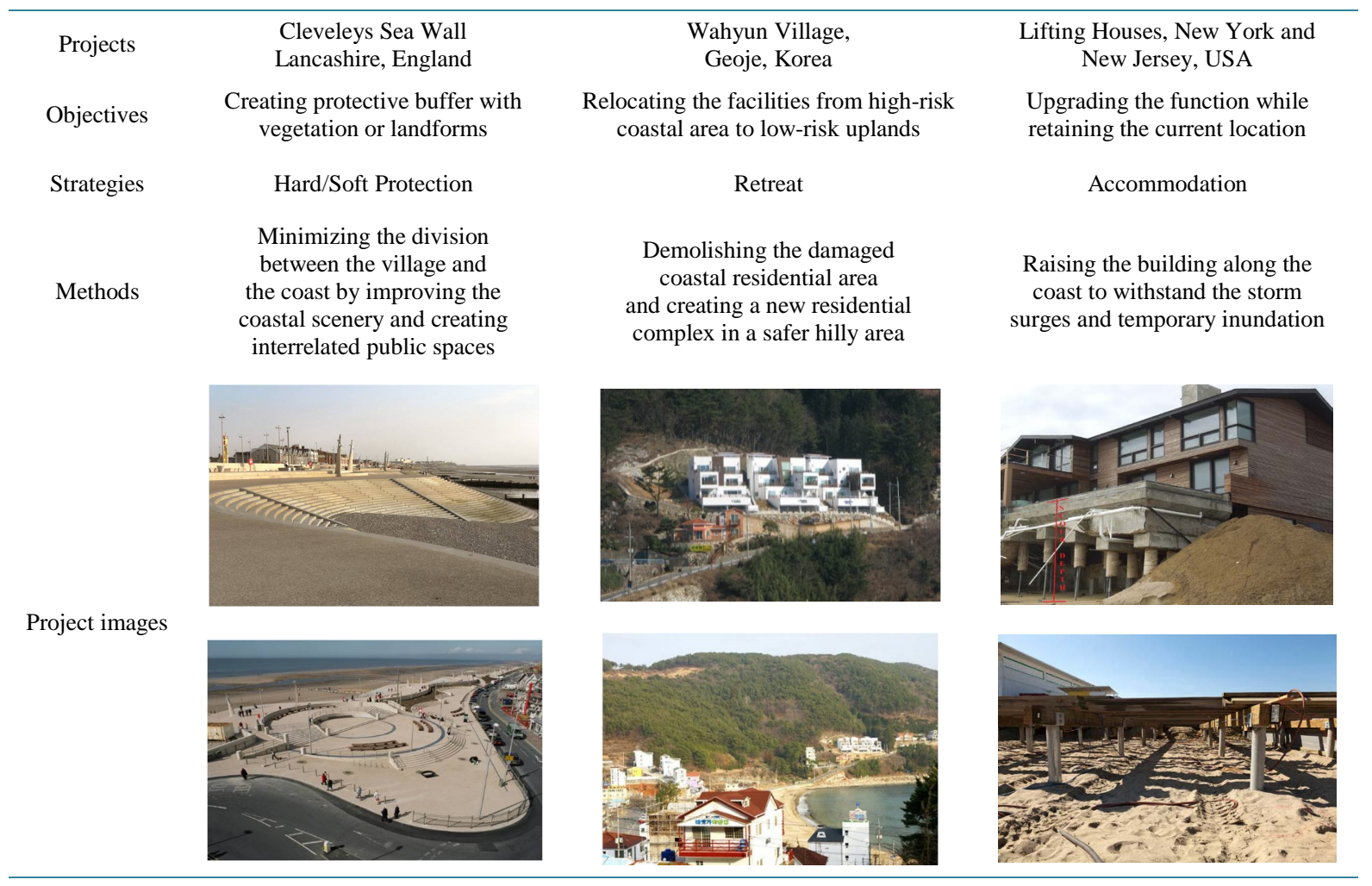

For the town of Cleveleys in Lancashire, United Kingdom, a new sea wall was designed to address the visual unattractiveness of the existing sea wall and to prevent the division between the town and its coast caused by the previous wall. The newly created sea wall was designed to provide a high-quality coastal space that would also protect the town from storm and flood, and furthermore, it became a new tourist attraction contributing to their local economy [9]. The project includes street furnishing, a pavilion, public art space, and lighting system, and an exhibition space, and has provided an improved public space offering people both accessibility and views of the seaside through promenades and shelters.

Wahyun Village of Geoje, Korea, suffered significant damage due to a typhoon called Maemi to the extent that the majority of houses on the coast were destroyed. Owing to government support, widespread public encouragement, and local residents' participation, the relocation project to move the old village toward uplands away from the seaside was completed in 4 years [10]. The houses on the coast were newly constructed, and a 500-m-long and 35-m-wide sandy beach was restored

Many coastal houses in New York and New Jersey have been damaged by Hurricane Sandy in 2012. The adaptive action taken to prevent flood damages and preserve the coastal communities involved lifting the buildings using pier structures. This remedy enables the residents to obtain the elevation certificate in order to mitigate future insurance claim for flood damage [11]. Lifting the buildings above the hazardous level can be considered as a temporary solution to coastal vulnerability when committed to maintain the coastal communities in place prior to relocating them.

These exemplary projects were implemented in response to storm damages, and they provided relevant ideas for the adaptive coastal design. Cleveleys Seawall utilized the landform as a protective buffer minimizing the division between the village and the coast by improving the scenery and creating interrelated public spaces. Wahyun Village was relocated from its highly vulnerable location in the coast to the low-risk uplands. Projects that involved lifting the houses upgraded the low-elevation houses along the coast to withstand storm surges and temporary inundation. Through these case studies, this research focused on three adaptive design strategies for the coastal area-soft protection, retreat, and accommodation-and investigated the possibility of defensive coastal designs considering the current storm damage as well as future climate change. 


\section{Research Site Analysis}

The east coast of Korea runs from the inlet of the Tumen River to Busan Quays, which is $1723 \mathrm{~km}$ long, and the section belonging to Gangwon Province is $318.3 \mathrm{~km}$ long, approximately $18.4 \%$ of the total length [12]. The total population of the Gangwon Province was approximately 1,150,000 as of 2010, and approximately 46\% of the population, which is over 530,000 people, was living in the Yeongdong region [13].

While multiple scenarios of rising sea levels are under investigation, this research took its core data from the inundation map created by the Korea Environmental Institute (KEI) in 2012 by considering the storm surges based on the prediction that sea levels will rise by $1.36 \mathrm{~m}$ by 2100 . The land cover map used in this research was produced in 2007 and modified in 2009. The medium classification land cover map developed by the Ministry of Environment and a digital map based on the ITRF 2000 ASTER DEM map were also used.

\subsection{Coastal Land Uses}

There are a number of sandy beaches and cities along the ports throughout the coast in Gangwon Province as shown in Figure 1. Many ports facilities were developed and expanded for fisheries and sea transportation, and coastal structures such as breakwaters and sea walls were constructed. The roads were builtalong the entire shoreline to accommodate the local travel and to appreciate coastal scenery.

The Yeongdong region consists of coastal areas on the east side of Daegwallyeong Ridge in the Tae baek Mountains as shown in Figure 2. The major cities in the Yeongdong region are geographically separated by

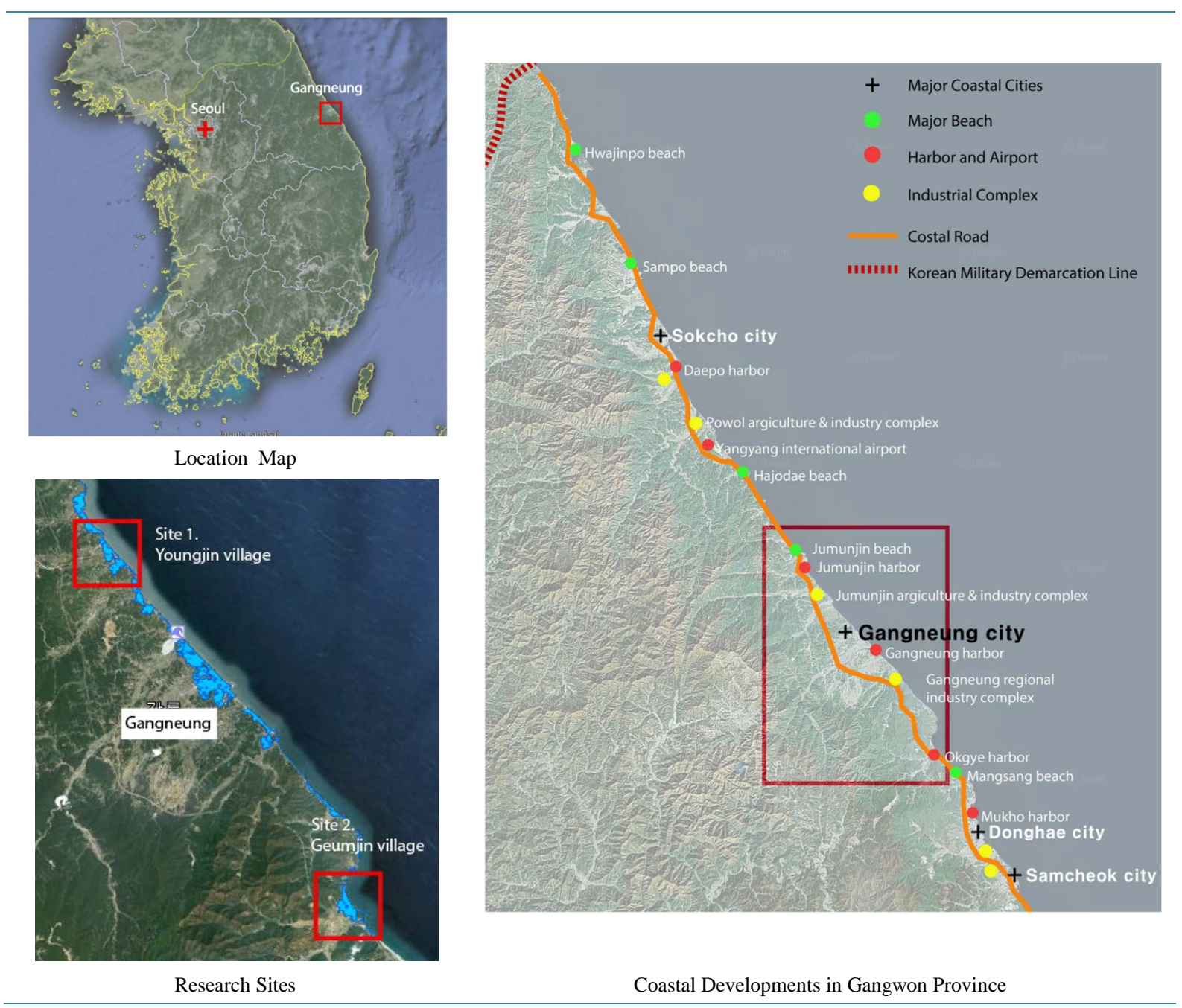

Figure 1. Site location map. 


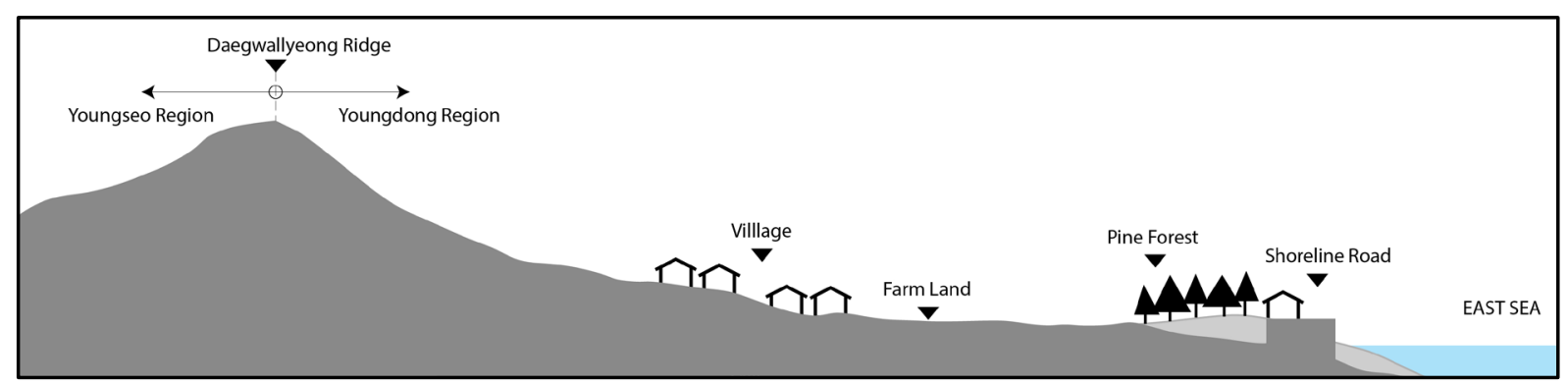

Figure 2. Coastal characteristics of Yeongdong Region.

high mountains on the landward side and located along the shoreline for their association with traditional ocean-related industry. For this reason, the physical expansion of cities and the growth of facilities caused by urbanization and industrialization have had a direct impact on the seashore.

\subsection{Coastal Flood and Erosion}

Over the 43 years from 1964 to 2006, wave heights of the east coast have reached $7 \mathrm{~m}$, as the sea level of the east coast has risen by $22 \mathrm{~cm}$. However, sea walls are only about 4 to $5 \mathrm{~m}$ high in the majority of ports on the east coast as they were built based on the heights of waves when designs for ports and coastal structures are set up in 1988. Thus, damage from flooding and erosion is increasing since overtopping occurs even during storms or heavy rain, let alone during powerful typhoons [14]. Therefore, the climate change adaptive strategy in Gangwon Province was developed focusing on areas susceptible to erosion rather than responding to the sea level rise inundation because higher and more powerful waves are anticipated with climate change.

In contrast to the southwest coast where reclamation projects have been implemented relying on the rias shoreline and the widespread tidelands, the shoreline of the east coast is well-defined and water depth is high while the movement of sand caused by waves dominates the beach development. Because the slope between the land and the ocean is steep, the seaside on the east coast mainly consists of sand and rock cliffs, and tidal mudflats have not developed. As indicated by the characteristics of the east coast, coastal erosion due to high waves is a major problem in the coastal areas of Gangwon Province, and 18 out of 34 sandy beaches on the east coast are severely eroded as shown in Figure 3 [14]. Although the amount of sand influx should remain constant in the coastal areas through the natural inflow of soil and sand from the adjacent mountainous areas, this is not the case because residential and commercial areas as well as shoreline roads are located throughout the east coast. This means that erosion is increasing throughout the coastal region, and artificial coastal projects and coastal structure designs are still being implemented. However, coastal structures are also continuously eroded by waves, which can accelerate the coastal erosion by blocking the natural flow of soil and sand. Hence, Gangwon Province needs to develop the design solutions to respond to the erosion problem and protect its coastline.

\section{Adaptive Design Strategies}

To analyze the erosion in the coastal areas of Gangneung, the largest coastal city in Yeongdong Region of Gangwon Province, two coastal areas with accelerating erosion problems were selected as research sites. The proposed design focuses on moving the shoreline roads as well as the residential and commercial areas adjacent to the coastal in land in order to prevent coastal erosion by facilitating the natural influx of soil and sand. The systematic adaptation plans for each area were created to reveal the topographical relationships and material movements of each area. The mean sea level of the section diagram was set according to the mean sea level in 2009 , and the expected sea level was predicted by taking into account a sea level rise of $1.36 \mathrm{~m}$ along with storm surges.

\subsection{Youngjin Village Area}

Youngjin is a small village in the northern part of Gangneung; approximately 60 households are engaged in fishery business utilizing the nearby Youngjin port. To protect the port from storm surges, lengthy sea walls, sand groins, and lighter's wharves were recently built in this port. Since the construction of these protective structures, tidal currents and sand flows have changed the sedimentation patterns blocking the port entrance. 


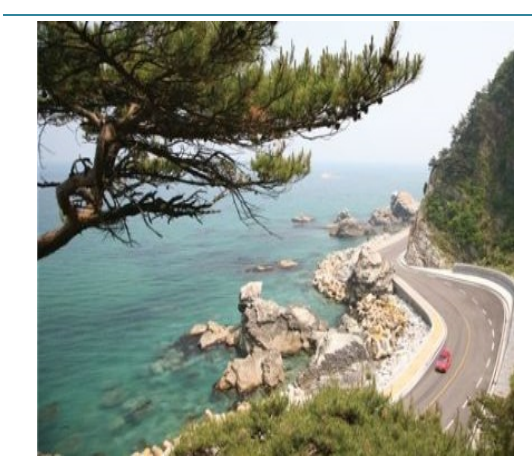

Shoreline road

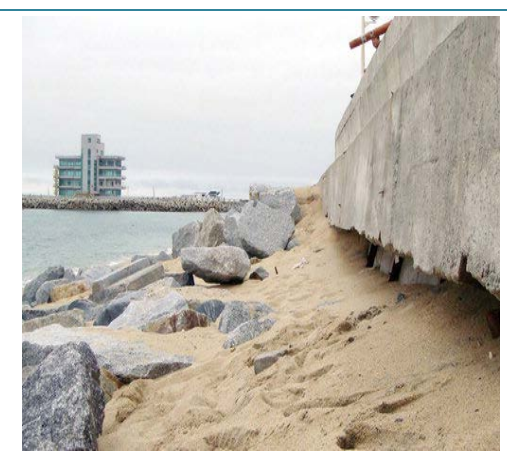

Coastal erosion

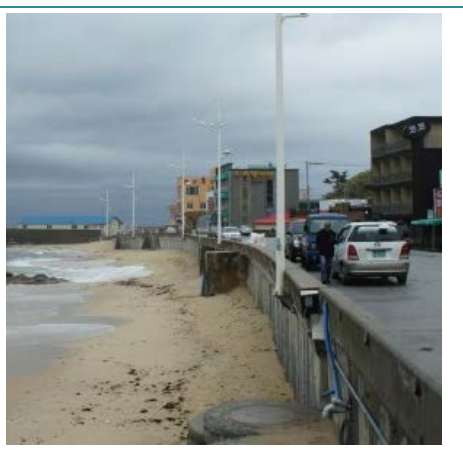

Squeezed beach

Figure 3. Typical coastal conditions of Gangwon Province.

The beaches at Youngjin and Yeongok are located in the north and south of the port, respectively (Figure 4). The white sand of Youngjin beach is $600 \mathrm{~m}$ in length and $1300 \mathrm{~m}^{2}$ in area. Although its size is small, the beach is consistently popular with tourists because it has ecological and leisure programs as well asa campsite [15]. Yeongok, a small-sized beach, is $700 \mathrm{~m}$ in length, $50 \mathrm{~m}$ in width, and approximately 35,000 $\mathrm{m}^{2}$ in area. On the north side of the beach, there is a wide pine forest behind the beach. Parking areas and shoreline roads are adjacent to these beaches and commercial facilities are located along the shoreline roads. As this aggravates the impact of waves, the coast has been eroded, revealing the substructure of the shoreline roads. These roads block the influx of soil and sand from the pine forest located behind the beach.

The main design strategy for this area is to reconnect the pine forest and the beach to allow the circulation of sand as shown in Figure 5. The pine forest is not only an ecological relief area that provides shade for the beach tourists during summer, but also facilitates the natural influx of soil and sand. When wave heights increase owing to rising sea levels, the forest will act as a natural buffer. To connect the pine forest and the beach to alleviate coastal erosion, the proposal shown in Figure 5 indicates that the shoreline roads and the adjacent commercial areas have been relocated in the hinterland of the pine forest.

\subsection{Geumjin Village Area}

Geumjin Beach is $900 \mathrm{~m}$ in length, $50 \mathrm{~m}$ in width, 45,000 $\mathrm{m}^{2}$ in area, and can accommodate 22,500 people. A shoreline road on the sea wall was developed along the beach, and the other side of the shoreline road is a small fishing town and the mountain behind it (Figure 6). The beach is located along the coastal terrace, and it has a steep slope towards the ocean. Recently, swell-like waves have occurred frequently on the east coast, exacerbating the erosion of the beach along the sea wall. Gumjin and Okgye are the major ports located on the north and south sides of the beach. Gumjin port is used by the residents whose livelihood is fishing, and Okgye port is a trading port that greatly contributes to the local industries.

The proposed design involves raising the coastal buildings to circulate water and sand. When the shoreline roads are relocated behind the raised buildings, they can be directly accessed from the building level because of the steep topography of the east coast. At the front of the coastal buildings, boardwalk promenades can facilitate the pedestrian access for residents and visitors while allowing the influx of water and sand as well as preserving the coastal scenery as shown in Figure 7.

\section{Conclusions and Discussion}

This research analyzed physical and environmental characteristics of Gangneung's coastal areas, situated on the east coast of Gangwon Province in Korea. Gangneung is susceptible to the effects of climate change, and the erosion damage from the storm surges and high swells are expected to be more serious problem than the inundation because of topographical and oceanographic characteristics of the east coast. Therefore, the adaptive design strategies are mainly focused on the accommodation and retreat strategies in order to maintain the coastlines.

The main aims of this research are to review the adaptation strategies in response to climate change through case studies and apply the findings to new research cases, and to analyze the research areas that are susceptible to climate change and propose adaptive design strategies through diagrams and three-dimensional representa- 


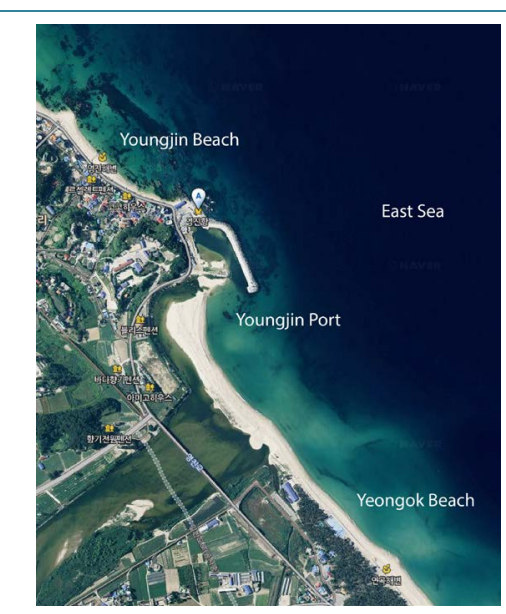

Aerial Map

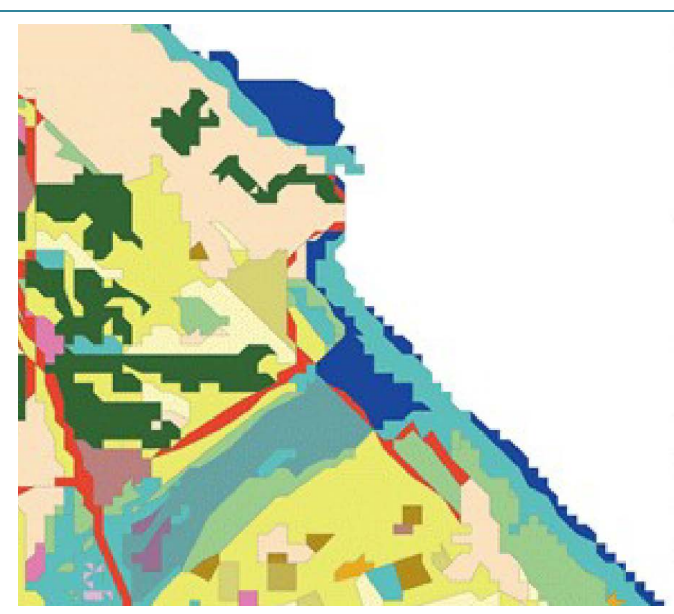

Land Cover Map

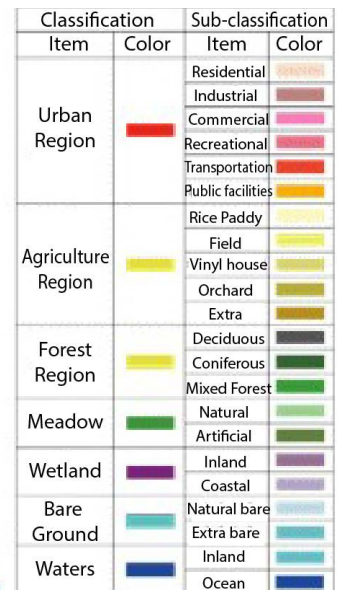

Waters $\mid$\begin{tabular}{|l|l|} 
Ocean \\
\hline
\end{tabular}

Figure 4. Youngjin Village site map.

Phase I

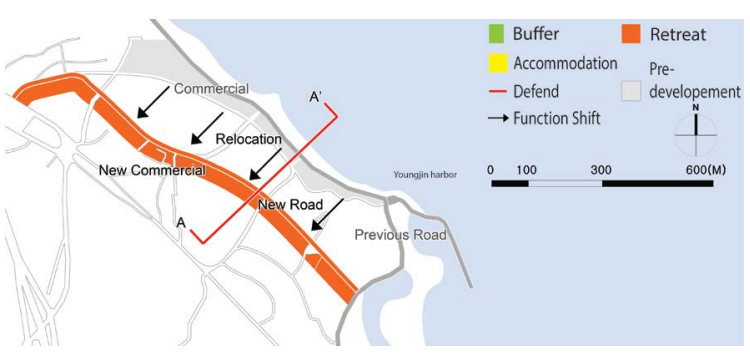

Plan

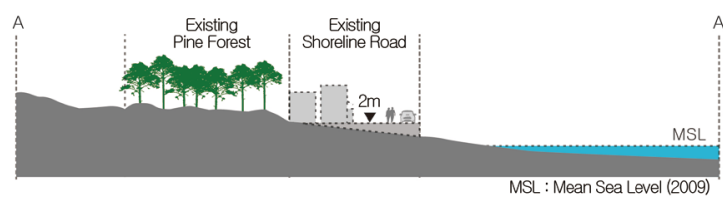

Section

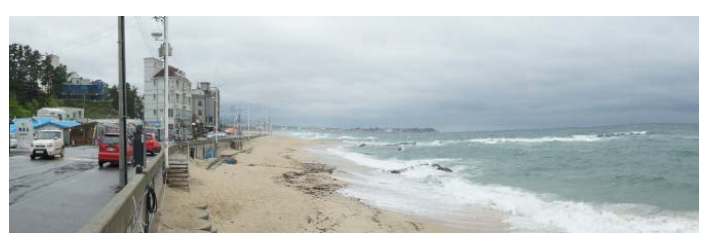

Perspective (Before)
Phase II

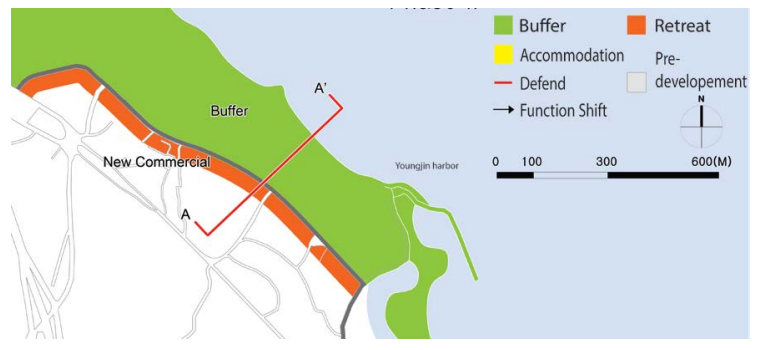

Plan

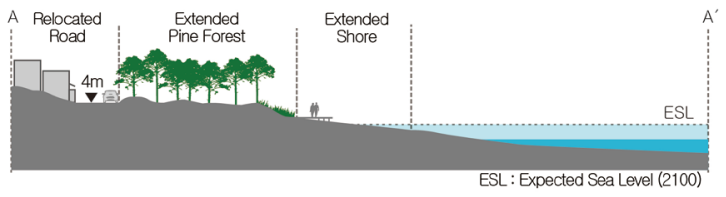

Section

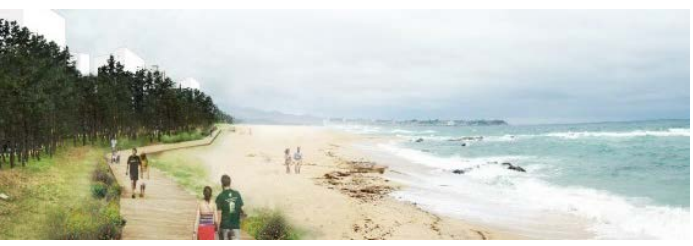

Perspective (After)

Figure 5. Youngjin Village design strategy.

tions. Youngjin and Geumjin Villages in the coastal areas of Gangneung were selected as research sites to experiment adaptive design strategies in response to climate change and rising sea levels. The design strategies for the adaptation are as follows: 1 ) for both areas, the shoreline roads adjacent to the coast are to be moved behind the pine forest to connect the forest to the beach; and 2) the coastal buildings are to be raised in order to prevent coastal erosion by facilitating natural influx of soil and sand. 


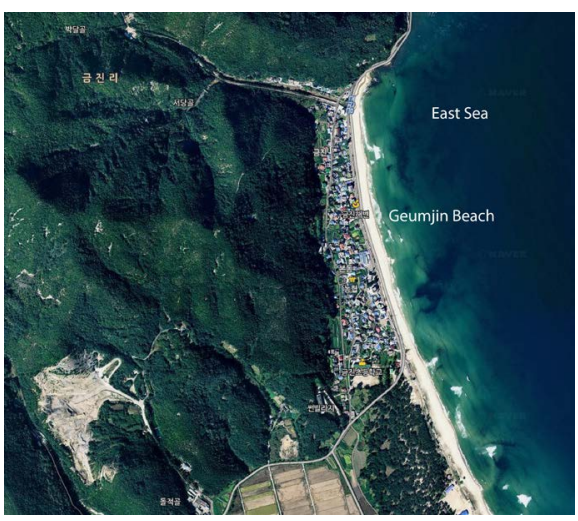

Aerial Map
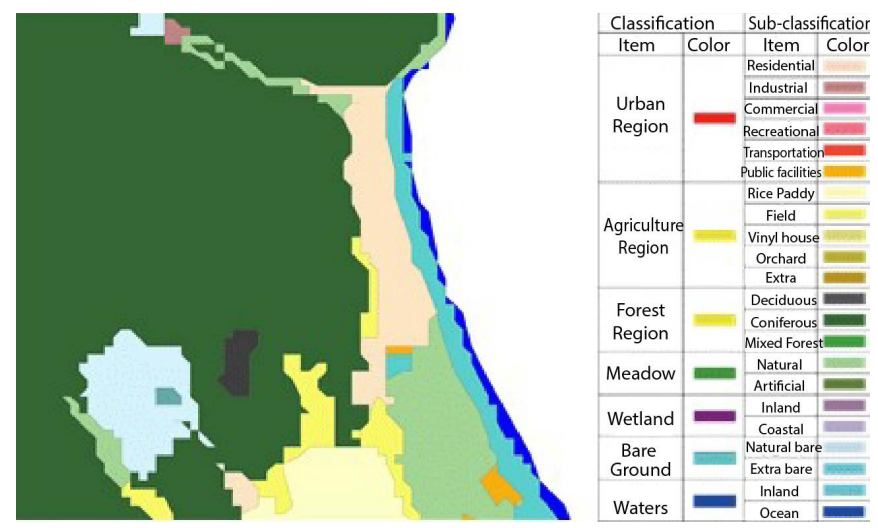

Land Cover Map

Figure 6. Geumjin Village site map.

Phase I

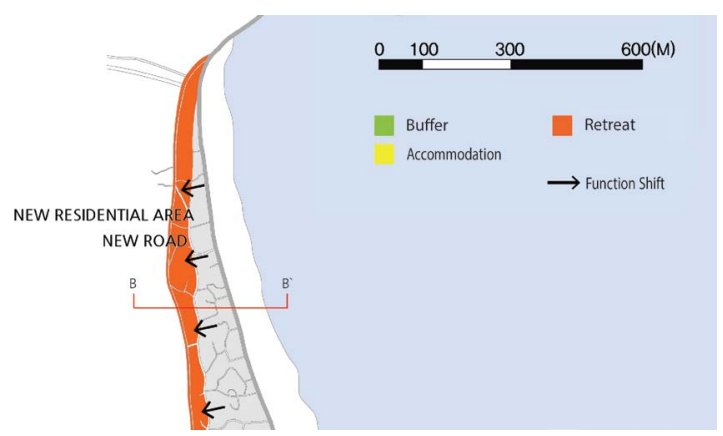

Plan

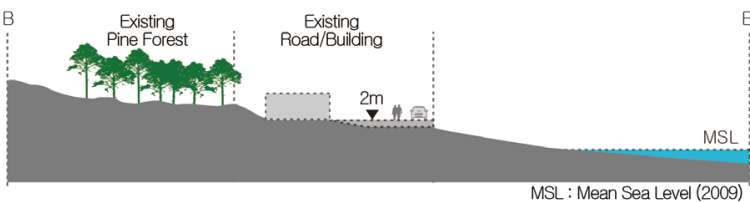

Section

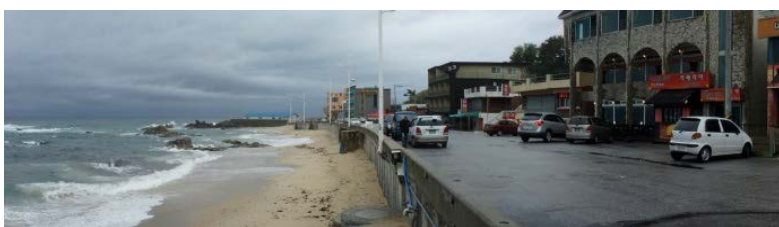

Perspective (before)
Phase II

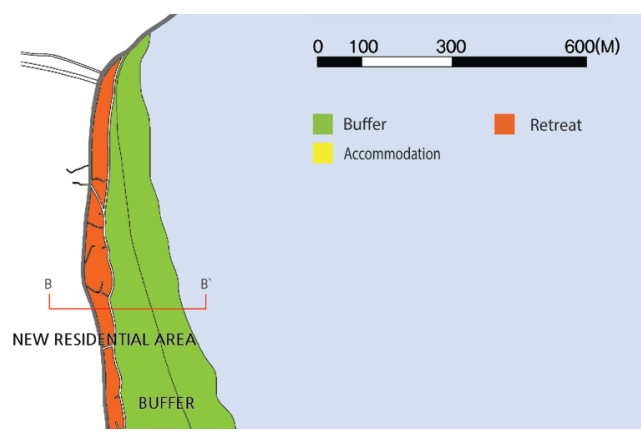

Plan

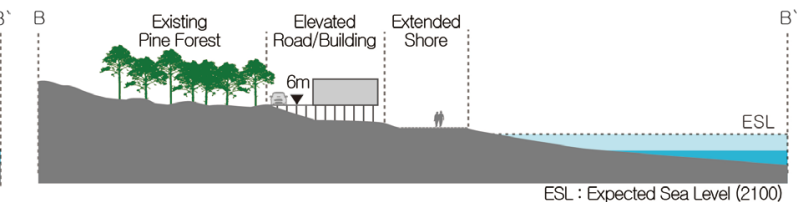

Section

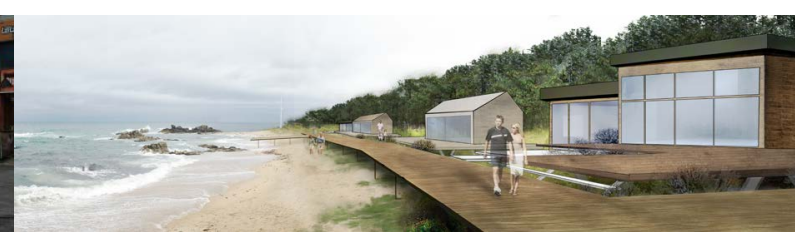

Perspective (after)

Figure 7. Geumjin Village design strategy.

This research has considerable potential to be used as an exemplary design adaptation to climate change for coastal areas. The research attempts to provide a basis for the land use policy in areas susceptible to erosion and flooding, to establish the guidelines for publicly funded developments, and to prepare long-term relocation plans for existing coastal developments in order to create a sustainable and resilient future for the coastal cities. 


\section{Acknowledgements}

The result of this research was initially presented in the report, National Assessment on Sea Level Rise Impact of Korean Coast in the Socioeconomic Context II, published by the Korea Environmental Institute in 2012. The author is grateful to the Korea Environment Institute for funding this research, and particularly Dr. Kwangwoo Cho, for providing related data including the inundation map. Graphic production and data collection for this research were supported by graduate students in Evolving Landscape Laboratory. The author thanks all participants for their assistance.

\section{References}

[1] Hallegatte, S., et al. (2011) Assessing Climate Change Impacts, Sea Level Rise and Storm Surge Risk in Port Cities: A Case Study on Copenhagen. Climatic Change, 104, 113-137. http://dx.doi.org/10.1007/s10584-010-9978-3

[2] Cooper, J.A. and Lemckert, C. (2012) Extreme Sea-Level Rise and Adaptation Options for Coastal Resort Cities: A Qualitative Assessment from the Gold Coast, Australia. Ocean \& Coastal Management, 64, 1-14. http://dx.doi.org/10.1016/j.ocecoaman.2012.04.001

[3] Nicholls, R.J. (1999) Increasing Flood Risk and Wetland Losses Due to Global Sea-Level Rise: Regional and Global Analyses. Global Environmental Change, 9, 69-87. http://dx.doi.org/10.1016/S0959-3780(99)00019-9

[4] Nicholls, R.J. (2004) Coastal Flooding and Wetland Loss in the 21st Century: Changes under the SRES Climate and Socio-Economic Scenarios. Global Environmental Change, 14, 69-86. http://dx.doi.org/10.1016/j.gloenvcha.2003.10.007

[5] Han, G., et al. (2007) An Alternative Physical Plan for Korea. Journal of the Urban Design Institute of Korea, 8, 6786.

[6] Cho, K., et al. (2012) National Assessment on Sea Level Rise Impact of Korean Coast in the Socio-Economic Context II. Report 2012-19. Korea Environment Institute, Seoul.

[7] Cho, K. and Maeng, J. (2007) Some Thoughts on Direction to Cope with the Sea Level Rise in Korea. Journal of the Korean Society of Marine Environmental Engineering, 10, 227-234.

[8] Lee, Y. (2014) Coastal Planning Strategies for Adaptation to Sea Level Rise: A Case Study of Mokpo, Korea. Journal of Building Construction and Planning Research, 2, 74-81. http://dx.doi.org/10.4236/jbcpr.2014.21007

[9] Cleveleys Sea Wall Report. http://www.cleveleys-seawall.co.uk/Reports/p 10-19-cleveley1 V32.pdf

[10] Wahyeon Village Relocation Project. http://www.wahyun.com/web

[11] Federal Emergency Management Agency (2013) Designing for Flood Levels above the BFE after Hurricane Sandy. http://www.fema.gov/media-library-data/1381405016896-8bdeadf634c366439c35568a588feb24/SandyRA5DesignAb oveBFE_508_FINAL2.pdf

[12] Hong, D. (2011) Coastal Managements and Restoration Works for Beach Erosion on the East Coast of Korea. Master Thesis, Gwandong University.

[13] Kim, J., et al. (2012) Gangwon Province General Plan (2012-2020). Research Institute for Gangwon.

[14] Ministry of Land, Transport and Maritime Affairs (2012) Coastal Erosion Monitoring Final Report2011.

[15] GangneungTourism Organization. http://tour.gangneung.go.kr 